Time-dependent effects of orientation, heterogeneity and composition determines benthic biological community recruitment patterns on subtidal artificial structures

\title{
Hanlon, N
}

http://hdl.handle.net/10026.1/12106

10.1016/j.ecoleng.2018.08.013

Ecological Engineering

Elsevier

All content in PEARL is protected by copyright law. Author manuscripts are made available in accordance with publisher policies. Please cite only the published version using the details provided on the item record or document. In the absence of an open licence (e.g. Creative Commons), permissions for further reuse of content should be sought from the publisher or author. 
Title: Time-dependent effects of orientation, heterogeneity and composition determines benthic biological community recruitment patterns on subtidal artificial structures

Authors: Nadine Hanlon ${ }^{1}$, Louise B. Firth ${ }^{1}$ and Antony M. Knights ${ }^{1}$

Affiliations: Marine Biology and Ecology Research Centre, School of Biological and Marine Sciences, Plymouth University, Drake Circus, Plymouth, PL4 8AA, UK

\section{Corresponding Author: aknights@plymouth.ac.uk}

Running Head: Manipulating recruitment on to artificial structures

\section{Highlights}

- Surface orientation, roughness and chemical composition alter recruitment over time

- Orientation (light) an early primary driver of community structure

- Roughness mitigates effects of surface orientation over time

- Addition of chemical cues may faciliatate 'selection' of ecosystem engineers

- Surface modifications enhance biodiversity, habitat function and service provision

\section{ABSTRACT}

Worldwide, coastlines are becoming increasingly hardened by infrastructure in response to population growth, need for space, and coastal protection. Coastal and marine infrastructure (CMI) supports fewer species and lower abundance and diversity than analogous natural rocky habitats, which can alter community composition and ecosystem functioning. Efforts to develop ecological engineering solutions that offset these negative consequences on biodiversity while retaining engineering function abound, but to date few studies have investigated the role of multiple factors simultaneously in driving patterns of biotic colonisation. Here, the role of surface heterogeneity, chemical composition and surface orientation was evaluated over a 6-month period. An increase in habitat heterogeneity, the replacement of shale for ground oyster shell (cue) and downward orientation was predicted to increase species richness, diversity and abundance. Orientation and heterogeneity greatly affected species richness, abundance, and community composition, and the inclusion of ground oyster shell (cue) increased bivalve recruitment but had only a marginal effect in community structure. Community formation was facilitated by low light but inhibited by sedimentation. On upward-facing surfaces, sediment accumulation on high complexity surfaces expanded niche heterogeneity, and supported communities comprised of burrowing polychaetes and predatory species. Surface orientation and heterogeneity are key factors influencing larval recruitment, and in supporting diverse benthic assemblages on artificial structures. These factors should be considered during the design phase of new engineering projects if the negative consequences of artificial structures are to be minimised while ensuring engineering function is maintained.

KEY WORDS: ecological engineering; urban sprawl; dynamics; intelligent design; selection; succession 


\section{INTRODUCTION}

Almost half the human population (Crossland et al. 2005) and three quarters of all large cities are located within 100km of the coast (Firth et al. 2016b; Neumann et al. 2015). With the growing trend of coastal migration and population growth rates expected to exceed 9.5 billion by 2050 (Gerland et al. 2014), anthropogenic pressures are placing increasing demands on coastal marine ecosystems (Airoldi and Beck 2007; Knights et al. 2015). As a result, increases in coastal and marine infrastructure (CMI), particularly associated with coastal protection and urbanisation (breakwaters, seawalls, piers and pontoons), and marine industry (shipping, renewable energy technologies, aquaculture), are dominating coastlines at the expense of natural habitats (Chapman 2003; Chee et al. 2017; Firth et al. 2016b).

Coastal hardening - the replacement of soft substrata with hard artificial structures - inevitably provides habitat for benthic communities (Airoldi and Bulleri 2011; Chapman 2003; Strain et al. 2018) and are known to alter connectivity patterns (Airoldi et al. 2015; Bishop et al. 2017). Artificial structures typically support lower abundance and richness of species than natural rocky habitats (Connell and Glasby 1999; Firth et al. 2013; Underwood and Anderson 1994) and have been reported to facilitate the establishment and spread of nonnative species, which can threaten native communities (Airoldi et al. 2015; Bracewell et al. 2012; Glasby et al. 2007). Recent focus has consequently been placed on ecological engineering (eco-engineering) which is the design of sustainable ecosystems for the mutual benefit of society and nature (Mitsch 2012). Experiments have incorporated natural reef features into CMI design, in attempts to offset the unfavourable impacts of artificial structures on marine ecosystems, whilst retaining structural integrity e.g. (Collins et al. 2002; Firth et al. 2016a; Loke and Todd 2016).

It has long been known that there is a positive relationship between biodiversity and habitat complexity (Hauser et al. 2006; Huston 1979; Underwood and Anderson 1994). In the marine environment, natural features, such as crevices, pits and water-retaining features, increase surface area, entrap nutrients, sediments and water and expand the range of niches available for colonisation and shelter (Crisp and Ryland 1960; Hauser et al. 2006; Loke et al. 2015). This complexity is paramount to supporting a diverse range of organisms. The physical complexity of natural reefs can also alter environmental conditions, such as exposure to light, temperature and water flow rates that result from the orientation of the surface (Thorson 1964). Shade is increasingly recognised as a key factor in the structure and functioning of intertidal and shallow subtidal benthic communities (Davies et al. 2014; Miller and Etter 2008; Vermeij and Bak 2002). Horizontal surfaces exposed to light typically promote algal growth, enhancing primary production but can be negatively affected by high sediment loading (Airoldi 2003). In contrast, shaded horizontally-oriented surfaces are typically dominated by invertebrates, such as ascidians, barnacles and bryozoans, where there is less competition for space with algae (Anderson and Underwood 1994; Knott et al. 2004).

The complexity of natural marine features can also alter water flow and boundary layer dynamics, potentially modifying larval supply and settlement (Knights and Walters 2010; Roberts et al. 1991). Reduced heterogeneity 
and the reduction in microhabitats provided by $\mathrm{CMI}$ may therefore be fundamental in explaining reduced species richness and differences in community composition simply as a result of altered physical drivers, when compared to natural reefs (Firth et al. 2016a; Moschella et al. 2005). An increasing number of studies are showing that $\mathrm{CMI}$ material and design modifications, which increase complexity without compromising the primary engineering function of the structure, can enhance recruitment, species richness, and diversity (Chapman and Blockley 2009; Evans et al. 2016; Firth et al. 2016a; Firth et al. 2014a).

Biogenic habitats are created by oysters, bivalves and polychaete worms (Cole and Knight Jones 1939; Dubois et al. 2002; Knights et al. 2012). Several factors can influence the settlement of larvae on biogenic habitats, including noise (Lillis et al. 2013), conspecific chemical cues (Browne and Zimmer 2001; Hadfield and Koehl 2001; Hay 2009), biofilms (Barnes et al. 2010; Pawlik 1992), and proteins and organic compounds in shell matrices (Crisp 1967; Vasquez et al. 2013). Biofilms are created by the accumulation of micro-organisms on clean surfaces when initially submerged. They coat hard casings and shells of pioneer species such as molluscs and polychaete worms, and significantly contribute to nutrient turnover and productivity (Sawall et al. 2012). Chemicals in the bacteria are strongly depended on for the settlement of larvae, particularly polychaete and mollusc species (Hadfield and Koehl 2001; Hay 2009; Pawlik 1992), and may be almost entirely responsible for the larval attraction of fouling community species (Paul et al. 2011). Bacterial biofilms formed by the bacterium Alteromonus colwelliana on oyster shells (Turner et al. 1994), are thought to produce metabolites that induce settlement of oyster larvae, enabling chemically-induced settlement to work on shells of both live and dead oysters (Tamburri et al. 1992). Larvae of many mollusc species will also settle in response to heterospecific cues (Neo et al. 2009; Vasquez et al. 2013), settling on hard shells of other species in the absence of primary hard substrata (Diederich 2005).

The chemical composition of material used for CMI has potential to influence benthic abundance, richness and diversity (McManus et al. 2017). Substrata comprising differential physical and chemical compositions can affect initial colonisation rates, succession, and subsequent species interactions (Anderson and Underwood 1994). The most common material used in over $50 \%$ of $\mathrm{CMI}$ is Portland cement, which offers advantages over other man-made materials, including high porosity, which is favoured by many species (Anderson and Underwood 1994; Pomerat and Weiss 1946). It is also easily adaptable to support complex structure designs and desirable habitat features (Firth et al. 2016a; Firth et al. 2014a; Loke and Todd 2016). However, the lime content found in concrete creates a highly alkaline surface, which is known to be toxic to some marine life upon initial submergence (Lukens and Selberg 2004). This can reduce initial rates of species colonisation (Nandakumar et al. 2003), such that CMI are not like-for-like substitutes for natural habitats (Sella and PerkolFinkel 2015).

This does not mean that CMI does not support life. Concrete is demonstrated to support diverse communities (Firth et al. 2016a; Sella and Perkol-Finkel 2015). In fact, marine fouling on the surface of concrete has been shown to enhance the structures durability through thermal protection (Coombes et al. 2017) and by slowing 
down the corrosive effects of chloride ion penetration (Kawabata et al. 2012). Biogenic build-up, such as the deposition of calcium carbonate by calcareous colonisers including serpulid worms and oysters, also offers bioprotection against weathering and erosion, protecting the structure and enhancing its longevity (Coombes et al. 2013). Therefore, efforts to increase the attractiveness of the structure to recruits may be beneficial to both ecosystem services and the longevity of the structure.

On artificial structures, the emergent composition of fouling communities not only depends on the order of larval recruitment and species identity, but also the construction material, its design, and the timing of its placement (Nandakumar 1996; Underwood and Anderson 1994). For example, the addition of organic materials can lower the $\mathrm{pH}$ of the concrete, and potentially encourage settlement of engineering species such as bivalves, worms and bryozoans (Sella and Perkol-Finkel 2015). To date, few eco-engineering designs have experimented with the incorporation of organic materials into CMI (but see Neo et al. 2009). The negative implications of creating artificial substrate and its replacement of natural habitats may potentially be offset through novel design and material choice, potentially reducing the negative consequences for biodiversity (Airoldi and Bulleri 2011) without compromising the original purpose of CMI, but a better understanding of succession and functioning of communities on artificial structures is needed.

Here, we compare recruitment onto concrete tiles manufactured with/without (i) ground oyster shell to replace shale, and (ii) habitat heterogeneity. Tiles were submerged for a period of 6 months and colonisation, succession and diversity assessed using a combination of monthly non-destructive sampling for the first 5 months and destructive sampling after 6 months. We hypothesised that (1) habitat complexity would support greater species richness and diversity; and (2) the replacement of shale with organic replacement would support different taxonomic and community composition compared to standard concrete. A final objective was to test if change in the orientation of the surface (upward or downward-facing used as a proxy for light) would alter recruitment patterns on to tile of different composition and heterogeneity.

\section{MATERIALS AND METHODS}

\section{Tile construction and deployment}

144 Individual concrete tiles $(15 \mathrm{~cm} \times 15 \mathrm{~cm} \times 1 \mathrm{~cm})$ were constructed with a patterned surface $(1 \mathrm{~cm}$ wide; $1 \mathrm{~cm}$

145 deep) on one side, and a smooth surface on the other (Fig 1). This tile size was chosen as it represents a

146 manageable experimental unit in terms of construction, deployment and taxonomic analysis. The block pattern

147 increased surface area by $25 \%$ over the smooth tile surface and represents a simple, cheap and easy to

148 implement modification to a standard artificial structure surface. Tiles were made using either: (i) standard

149 concrete mix of 1.5:1.5:1 (sand:shale:Portland cement), or (ii) with complete replacement of the shale

150 component of the mix for ground oyster (Magallana (formerly Crassostrea) gigas) cultch, which may provide

151 an olfactory cue for larval settlement (e.g. O'Connor et al. 2008). Other materials may also provide a cue but

152 are not tested here. All tiles were reinforced with an internal plastic-coated metal mesh grid and cured for 2-

153 wk. Twenty replicates of each tile type were made and randomly allocated to four treatments ( $N=80)$ : smooth- 
surface, standard concrete (SO-); smooth-surface with oyster shell (SO+); patterned-surface, standard concrete (PO-); and patterned-surface with oyster shell (PO+).

Tiles were suspended from floating pontoons at Port Pendennis Marina, Falmouth, UK (509'6.54" N, $5^{\circ} 3^{\prime} 39.21^{\prime \prime} \mathrm{W}$ ) on $3 \mathrm{~m}$ lengths of polyethylene rope. The marina is located in a sheltered position at the mouth of the River Fal and the moorings are adjacent to moorings for international cruise ships and a dockyard. Four tiles (one of each type) were randomly assigned to 1 of 4 positions on a rope (Fig. 1a), and spaced $25 \mathrm{~cm}$ apart, resulting in tiles at 2.25, 2.5, 2.75 and $3 \mathrm{~m}$ below the sea surface. A preliminary test of light intensity at the surface of each tile revealed no differences between positions. Ten tiles of each type (see above) were orientated with the patterned surface facing upward (flat surface down) and ten with the patterned surface facing downward (flat surface up).
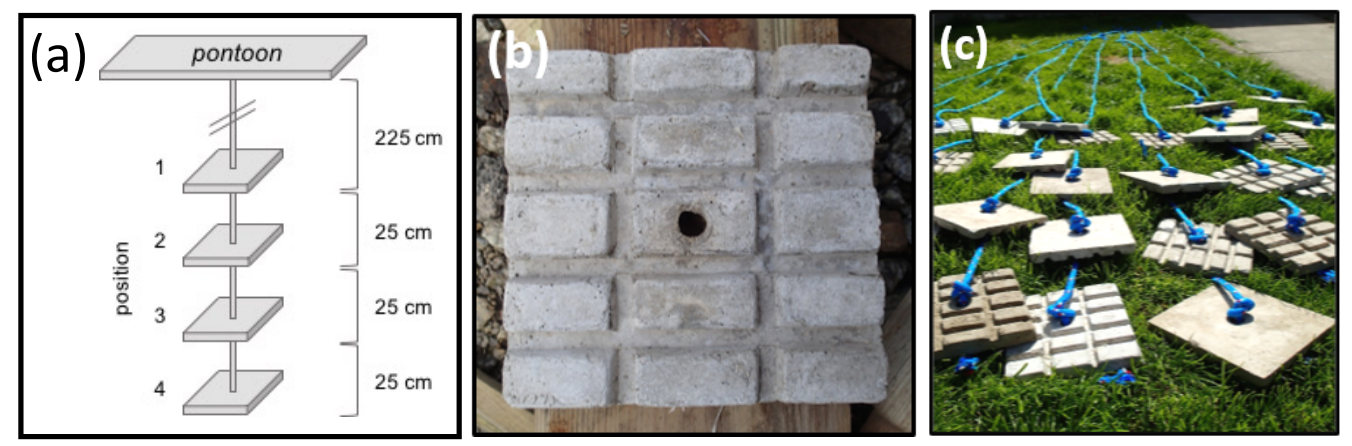

Figure 1. (a) Schematic of tile arrangement on a rope; (b) a tile with an embedded pattern design; and (c) assembled tile ropes.

\section{Sampling}

Tiles were deployed in April 2016 and colonisation and community assemblage changes were monitored over a 6-month period. Tile introduction was timed to capture the main recruitment window for many marine species in the UK (Knights et al. 2016). For months 1-5, all tiles were removed from the water, the upward and downward-facing surfaces of each tile photographed with a digital camera, then returned to the water (within 10 minutes to minimise stress to plants and animals on the tiles between sampling periods). Given an aim was to evaluate succession on tiles, species identification in months 1-5 could not be done using destructive sampling. As such, the resolution of the sampling limited the identification of organisms to phyla and percentage live cover per phyla, which were estimated using image analysis in ImageJ (Abramoff et al. 2004). After 6 months, all tiles were removed from the water and transported to Plymouth University Marine Station, where they were suspended in aerated, ambient sea temperature flow-through seawater tanks (salinity = 35) until they were destructively sampled. Tile were removed after 6-months due to logistical constraints. On both tile surfaces, the identity of all organisms was assessed to their lowest operational taxonomic unit (OTU) using standard taxonomic keys, and their abundance enumerated. Quantification of live cover of species on each tile was determined using a $1 \mathrm{~cm} \times 1 \mathrm{~cm}$ grid. Data recorded included: (i) percent cover of colonial organisms and 
single-species dominated assemblages (e.g. clusters of barnacles and serpulid worms, sponges, bryozoans), and (ii) individual counts (total abundance) of solitary sessile and mobile organisms.

\section{Statistical Analyses}

189 All analyses were performed using the open-source software package, R Version 3.4.3 (R Development Core

190 Team 2017). All data were normal and variances were homogeneous. Evidence of temporal autocorrelation as

191 a result of repeated measurement of tiles over time was tested using the ACF function in the nlme package,

192 and where relevant, an autoregressive-1 (AR1) or ARMA (autocorrelation-moving average) autocorrelation

193 structure was included in the model. Akaiki Information Criterion (AIC) was used to differentiate between

194 model fits.

195

Month 1-5

A generalised least squares (GLS) model tested for differences in the number of phyla and percent cover across all treatments. Tukey HSD post-hoc pairwise comparisons were used to determine differences between levels within factors. Localised regression (LOESS) was used to plot changes in mean number of phyla and abundance (\% live cover) for each tile surface over time.

201

\section{Month 6}

203 To standardise data for the effect of the increased surface area on patterned tiles, abundance counts were converted to densities. ANOVA was used to test for differences in species number, density, and ShannonWiener diversity $\left(H^{\prime}\right)$ between tile treatments. Significant differences between levels within factors were assessed using Tukey HSD posthoc pairwise comparisons.

Rank clocks (the coord_polar() function in ggplot2) were used to illustrate change in mean species abundance within treatment combinations over time. A 3-factor permuted multivariate ANOVA (PERMANOVA) with 9999 permutations (Anderson 2003) was used to test differences in community structure using the following fixed factors (levels): orientation (up; down); heterogeneity (flat; patterned); and shale-oyster replacement (shale; oyster). Bray-Curtis index was used to construct dissimilarity matrices (Clarke and Warwick 1998). Analyses were performed using ADONIS ('vegan' package, Oksanen et al. 2016) to test hypotheses and SIMPROF

214 (Similarity percentages) used to determine species most influential in causing similarity among tiles within treatments and dissimilarity among different treatments. Non-metric multidimensional scaling (nMDS) was used to graphically represent trends in multivariate data.

\section{RESULTS}

219 Month 1-5

220 A total of 18 taxa from 8 phyla were identified on tiles using non-destructive sampling methods. Orientation 221 had a significant effect on the number of OTUs present on tiles over time (Table $1 ; p<0.0001$ ). Downward-

222 facing tiles were colonised rapidly, with the number of OTUs after 5 months ( $\sim 5)$ not significantly different to 
month 1. In contrast, upward-facing tiles were slower to be colonised ( 3 OTUs after 1 month), but the number of OTUs gradually increased in over time (Fig. 2a) to the point where they were comparable to downwardfacing tiles after 5 months submersion. Adding heterogeneity also led to a small but significant increase in the number of OTUs in comparison to a flat substrate ( $p<0.001$, Table 1 , Fig. $2 b)$.

A combination of tile orientation and heterogeneity led to markedly different live percentage cover on tiles over time (Table 1; $p$ 0.05). Downward-facing tiles had significantly more live cover than upward-facing tiles at any given time and cover rapidly increased between sampling periods (Fig. 2c), although heterogeneity had little effect on percentage cover on these tiles. In contrast, the addition of heterogeneity on upward-facing tiles led to nearly $50 \%$ increases in percentage cover for each time point (Fig. 2c). After 5 months, percentage cover on downward-facing tiles was $\sim 4 x$ greater than on upward-facing tiles.

The communities on downward and upward-facing tiles differed to some extent, although both were dominated by the Ascidian (Ciona intestinalis) which represented, on average, $94.4 \%$ of the total assemblage across all tile surfaces after 3 months (Fig. 3). The growth of this taxa in particular led to rapid covering of downward-facing tiles, in addition to relatively large abundances of Annelids (Pomatoceros lamarkii), the nonnative barnacle (Austrominius modestus) and bryozoan (Bugula neritina). Upward-facing tiles also supported these dominant species as well as the red algae (Pterothamnion plumula), but in general, abundances tended to be much lower (Fig. 3). Replacement of shale with ground oyster shell had no effect on either the number of OTUs or percentage cover of flora and fauna on tiles (Table 1).

\section{Month 6}

After 6 months, tiles were destructively sampled and 81 species from 14 phyla were identified (Supplemental Material). There was no significant difference in Shannon-Wiener diversity $\left(F_{7,72}=1.66, p>0.05\right)$ irrespective of orientation, heterogeneity or shale replacement. There was, however, highly significant differences in mean species richness $\left(F_{7,72}=986, p<0.0001\right)$ (Fig. 4) among treatments. Maximum richness occurred on downwardfacing tiles ( 25 spp. per tile), but heterogeneity had no effect (Fig. 4a). In contrast, richness was generally lower on upward-facing tiles, although the addition of heterogeneity led to significant increases in species richness of $\sim 5$ spp. per tile. This pattern was mirrored for percentage live cover estimates (Fig. 4b).

After 6 months submersion, there were significant differences in community composition due to heterogeneity and orientation (orientation $\times$ heterogeneity: $F_{1,72}=6.68, p<0.01$ ). Differences were largely driven by four species; the abundance of the annelid Pomatoceros lamarckii, saddle oyster Anomia ephippium, ascidian Ascidiella scabra, and barnacle Austrominius modestus (Table 2c). The emergent communities on upwardfacing tiles were more variable than downward-facing tiles (Fig. 5) and dependent on heterogeneity. Rhodophyta, Chlorophyta and Nemertea were strongly correlated with upward-facing flat surfaces (Fig. 5), whereas platyhelminthes and arthropods were more associated with upward-facing patterned surfaces. Adding heterogeneity had no effect on the community composition on downward-facing surfaces. Protozoa (e.g. 
Folliculina sp.) were most strongly associated with downward-facing surfaces as well as Chordata, Cnidaria, and Echinoderms. A number of phyla (Annelida, Porifera, Mollusca) were ubiquitous on all tiles but tended more strongly toward downward-facing surfaces (Fig. 5).

The replacement of shale with ground oyster shell led to modest differences in the emergent community structure $\left(F_{1,72}=3.11, p<0.05, R^{2}=0.03\right)$ in addition to orientation and the addition of heterogeneity, although there was no obvious and clear pattern to the dissimilarity as a result of this factor. Restricting the analyses to a comparison of Molluscan abundance (specifically A. ephippium, Hiatella arctica, and Musculas costulatas; no M. gigas recruited) revealed some pattern; Mollusc abundance on surfaces constructed with oyster shell was $37.6 \%$ higher than on tiles constructed using shale. Importantly, no invasive species (including M. gigas) were recorded on any tiles during the experiment.

272

Table 1. Generalised least square regression (GLS) comparing mean number of OTUs and mean abundance (percentage cover) across orientation, heterogeneity, and shale-replacement treatments over time from months one to five. Significant $P$-values are shown in bold.

\begin{tabular}{|c|c|c|c|c|c|}
\hline \multirow[b]{2}{*}{ Source of Variation } & \multirow[b]{2}{*}{$\mathrm{df}$} & \multicolumn{2}{|c|}{ Number of OTU } & \multicolumn{2}{|c|}{ Percentage Cover } \\
\hline & & $F$ & $P$ & $F$ & $P$ \\
\hline Cue & 1 & 3.65 & 0.057 & 0.17 & 0.68 \\
\hline Heterogeneity & 1 & 11.27 & $<0.001$ & 15.24 & $<0.0001$ \\
\hline Orientation & 1 & 53.58 & $<0.0001$ & 173.75 & $<0.0001$ \\
\hline Time & 1 & 35.75 & $<0.0001$ & 100.50 & $<0.0001$ \\
\hline Cue $\times$ Heterogeneity & 1 & 0.03 & 0.87 & 0.12 & 0.73 \\
\hline Cue $\times$ Orientation & 1 & 3.07 & 0.08 & 0.73 & 0.39 \\
\hline Heterogeneity $\times$ Orientation & 1 & 1.50 & 0.22 & 10.29 & $<0.01$ \\
\hline Cue $\times$ Time & 1 & 0.102 & 0.75 & 0.18 & 0.67 \\
\hline Heterogeneity $\times$ Time & 1 & 0.64 & 0.42 & 2.10 & 0.15 \\
\hline Orientation $\times$ Time & 1 & 39.29 & $<0.0001$ & 45.07 & $<0.001$ \\
\hline Cue $\times$ Heterogeneity $\times$ Orientation & 1 & 1.47 & 0.23 & 0.003 & 0.96 \\
\hline Cue $\times$ Heterogeneity $\times$ Time & 1 & 0.001 & 0.98 & 0.33 & 0.57 \\
\hline Cue $\times$ Orientation $\times$ Time & 1 & 0.065 & 0.79 & 0.71 & 0.39 \\
\hline Heterogeneity $\times$ Orientation $\times$ Time & 1 & 3.62 & 0.057 & 4.29 & $<0.05$ \\
\hline Cue $\times$ Heterogeneity $\times$ Orientation $\times$ Time & 1 & 0.351 & 0.55 & 0.74 & 0.39 \\
\hline Residual & 367 & & & & \\
\hline
\end{tabular}


(a)

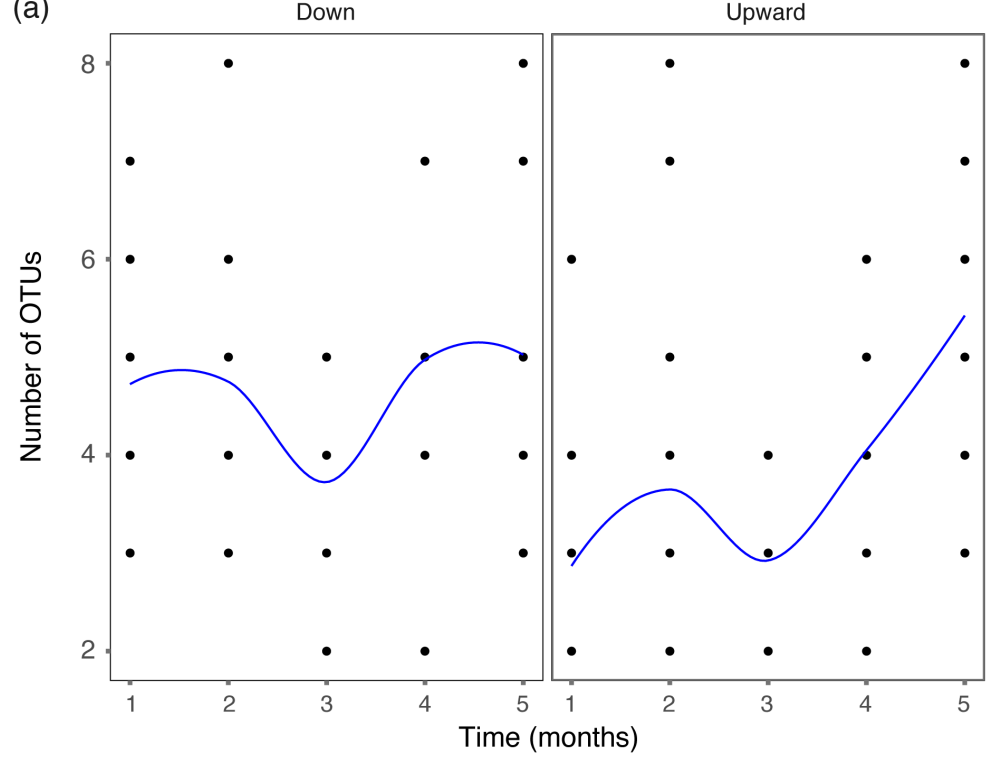

(b)

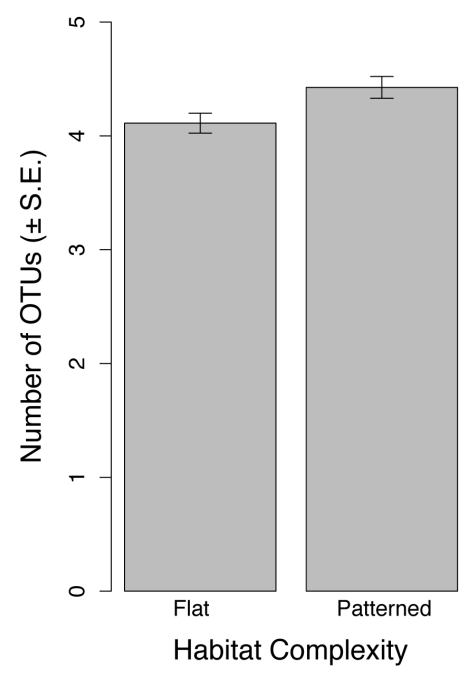

(c)
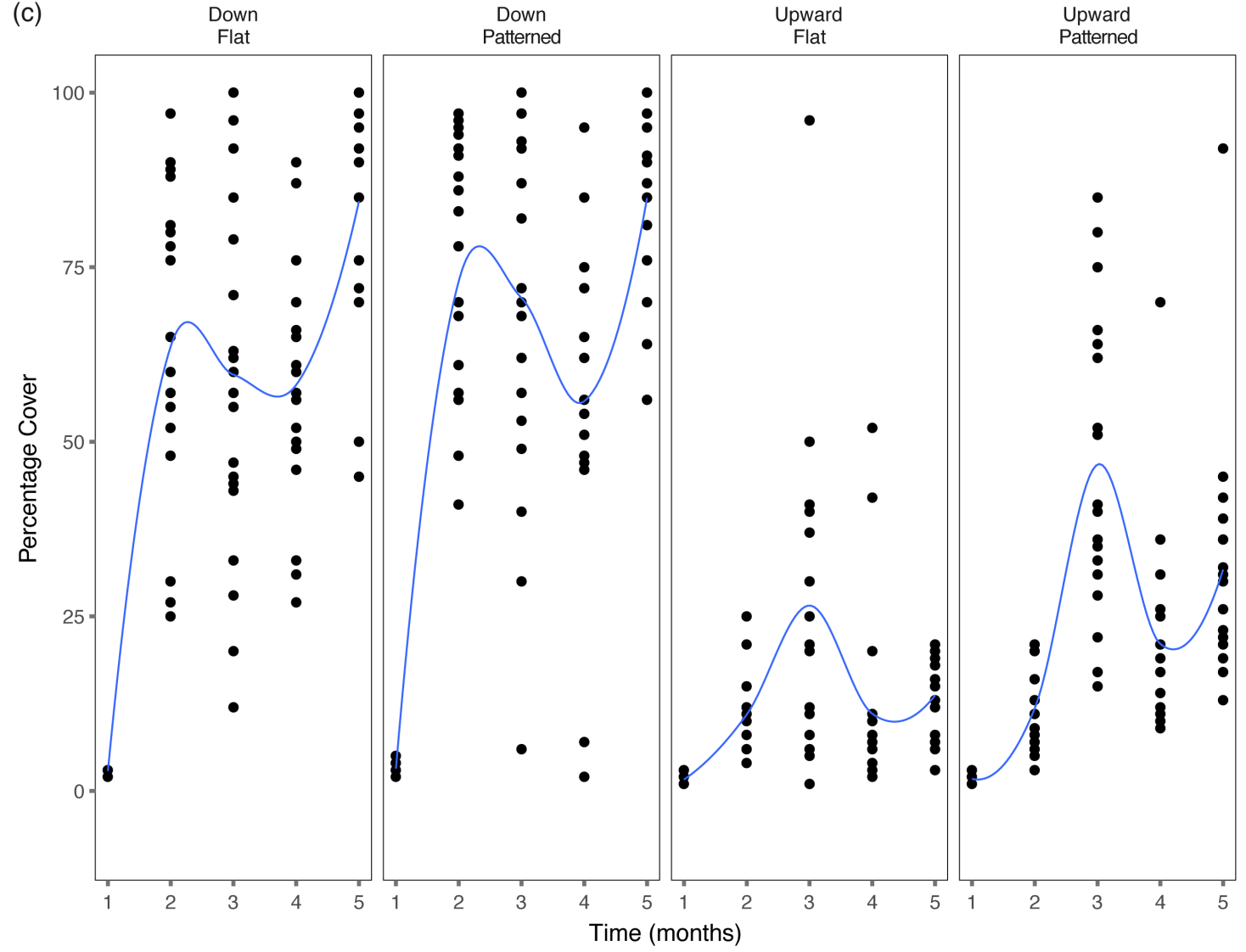

Figure 2. Number of OTUs (a) by tile orientation over time, (b) heterogeneity (mean \pm S.E.), and (c) change in percentage cover over time on downward and upward-facing tiles of differing heterogeneity (flat; patterned). Significant regression lines are shown and fitted using smoothed localised regression (LOESS). 


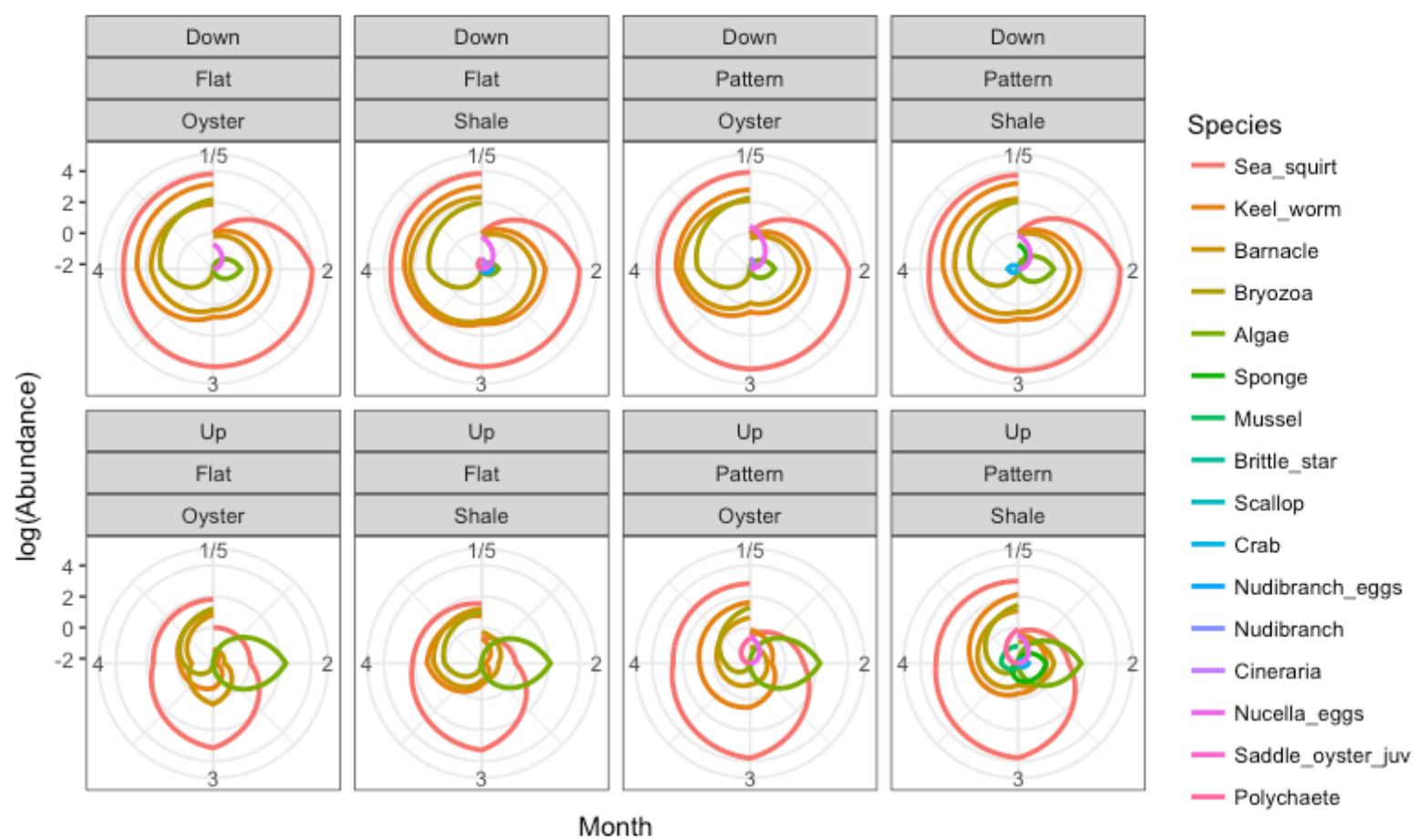

Month

284 Figure 3. Rank clocks of mean log(abundance) of species across treatments (orientation (down/up);

285 heterogeneity (flat/pattern); shale replacement (oyster/shale) at monthly intervals (1-5 months) after submersion (April - September 2016) $(N=400)$. The species list is ordered by relative contribution. 

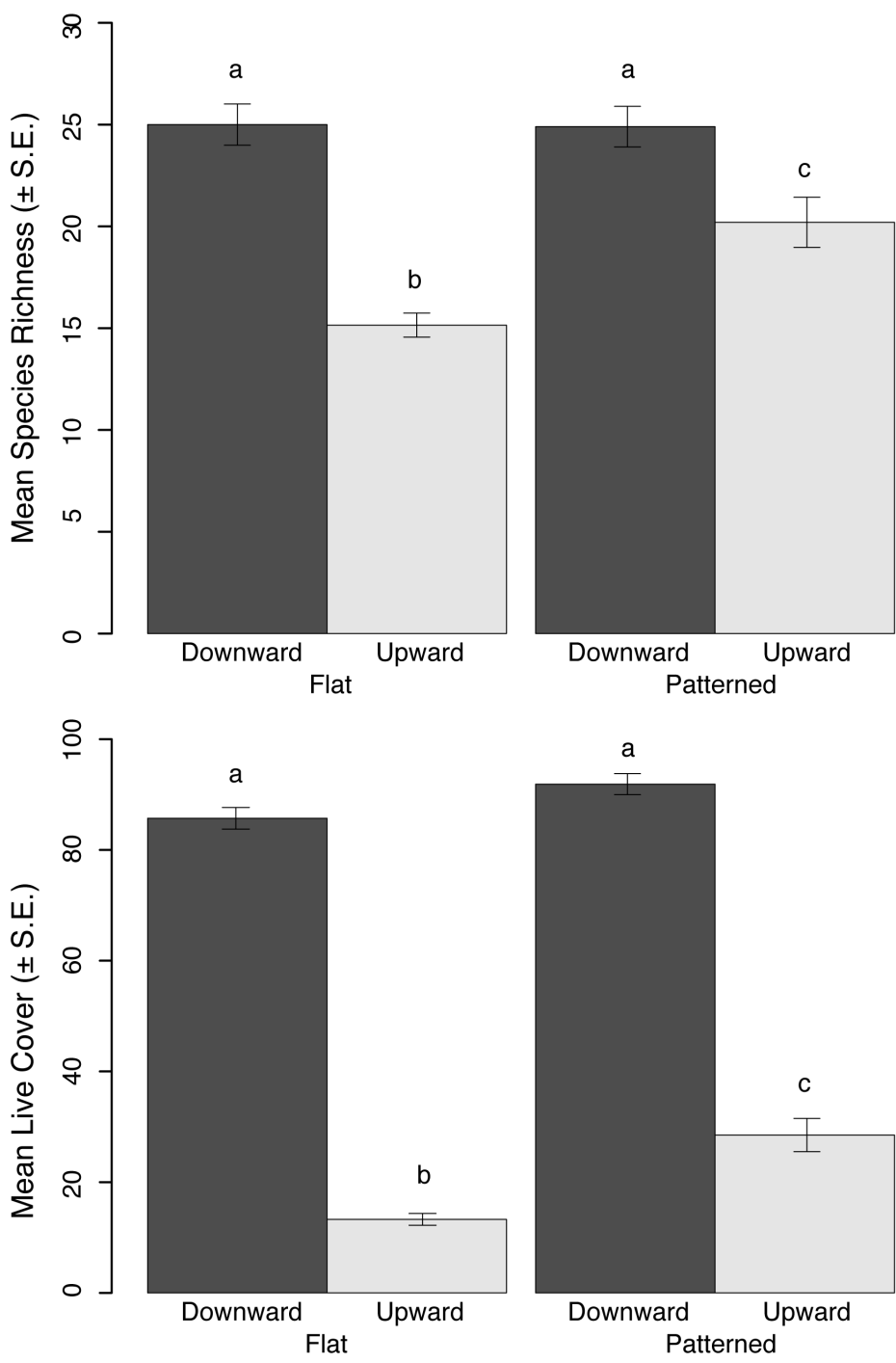

Figure 4. Comparison of species richness (top) and mean percent live cover (bottom) between treatments

290 after six months submersion $(\mathrm{N}=80)$. Error bars show standard error. Letters above bars indicate outcomes of

291 posthoc pairwise comparisons (Tukey HSD), where same letters indicate no difference between group means ( $p$ $>0.05)$. 
Table 2. (a) ANOVA comparing mean number of Operational Taxonomic Units (OTUs) and mean live cover among orientations, heterogeneities and concrete composition after 6 months. Post-hoc pair-wise comparisons of orientation and heterogeneity groupings. Significant $P$-values are shown in bold.

(a) Univariate ANOVA of total percent cover and species richness

\begin{tabular}{|c|c|c|c|c|c|}
\hline \multirow[b]{2}{*}{ Source } & \multicolumn{3}{|c|}{ Number of OTUs } & \multicolumn{2}{|c|}{ Percentage Live Cover } \\
\hline & $\mathrm{df}$ & $F$ & $P$ & $F$ & $P$ \\
\hline Orientation & 1 & 53.48 & $<0.0001$ & 1035.05 & $<0.0001$ \\
\hline Heterogeneity & 1 & 1.77 & 0.18 & 25.69 & $<0.0001$ \\
\hline Cue & 1 & 6.19 & $<0.05$ & 2.07 & 0.15 \\
\hline Orientation $\mathrm{x}$ Heterogeneity & 1 & 0.006 & 0.94 & 4.62 & $<0.05$ \\
\hline Orientation $\times$ Cue & 1 & 6.70 & $<0.05$ & 0.005 & 0.94 \\
\hline Heterogeneity $x$ Cue & 1 & 0.87 & 0.36 & 0.48 & 0.49 \\
\hline Orientation $\mathrm{x}$ Heterogeneity $\mathrm{x}$ Cue & 1 & 0.006 & 0.94 & 0.08 & 0.77 \\
\hline Residual & 72 & & & & \\
\hline
\end{tabular}

301

302

(b) PERMANOVA of species percent cover (colonial species) and abundance (singular individuals)

\begin{tabular}{llllll}
\hline Source & $\mathrm{df}$ & $\mathrm{MS}$ & $F$ & $P$ & $\mathrm{R}^{2}$ \\
Orientation & 1 & 5.35 & 47.67 & $<0.001$ & 0.35 \\
Heterogeneity & 1 & 0.53 & 4.68 & $<0.05$ & 0.03 \\
Cue & 1 & 0.31 & 2.78 & $<0.05$ & 0.02 \\
Orientation x Heterogeneity & 1 & 0.42 & 3.72 & $<0.01$ & 0.03 \\
Orientation x Cue & 1 & 0.16 & 1.46 & 0.15 & 0.01 \\
Heterogeneity x Cue & 1 & 0.09 & 0.84 & 0.50 & $<0.01$ \\
Orientation x Heterogeneity x Cue & 1 & 0.09 & 0.81 & 0.52 & $<0.01$ \\
Residual & 72 & 0.1169 & & & \\
\hline
\end{tabular}

303

(c) SIMPROF analysis of the most influential phyla and species contributing to the differences in community assemblages between levels within complexity and orientation treatments after 6-months.

\begin{tabular}{lll}
\hline Phyla & Heterogeneity & Orientation \\
\hline Chordata & $29.1 \%$ & $30.1 \%$ \\
Mollusca & $52.2 \%$ & - \\
Annelida & $71.2 \%$ & $51.0 \%$ \\
Mollusca & - & $71.2 \%$
\end{tabular}

\begin{tabular}{lll}
\hline Species & Heterogeneity & Orientation \\
\hline Ciona instestinalis & $16.5 \%$ & $21.0 \%$ \\
Anomia ephippium & $30.4 \%$ & $35.9 \%$ \\
Pomatoceros lamarckii & $40.2 \%$ & $48.0 \%$ \\
Ascidiella scabra & $47.4 \%$ & - \\
Austrominius modestus & $53.8 \%$ & $55.6 \%$ \\
\hline
\end{tabular}




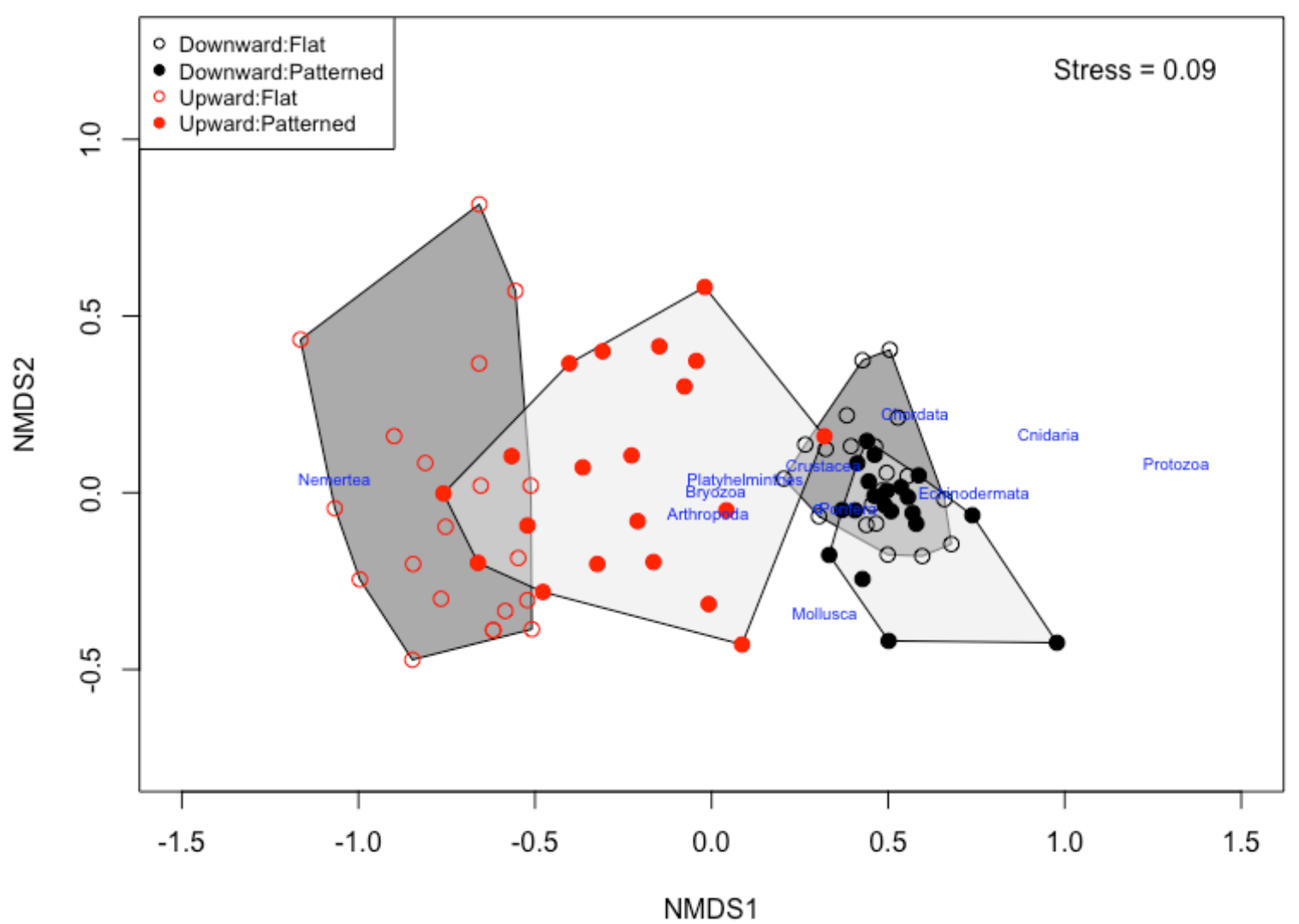

Figure 5. nMDS plot of dissimilarity in phyla composition after 6 months of submersion $(N=80)$. Points shapes and colour definitions are shown in the legend. Polygons indicate the dispersion of points within orientation. NB Centroids (xy coordinates) for Chlorophyta $(-5.04,0.19)$ and Rhodophyta $(-4.64,0.05)$ are not shown for clarity.

\section{DISCUSSION}

The replacement of natural habitats with artificial structures in the marine environment has led to concerted effort to enhance biodiversity using a combination of design and material modifications (Strain et al. 2018). Here, the change in community composition over a 6-month period on recruitment tiles in response to addition of surface heterogeneity (pits/crevices), a change in the composition of the construction material, and orientation of the surface (a proxy for light) was simultaneously tested. The importance of orientation and surface heterogeneity on species richness, percentage live cover and abundance changed over time, but the replacement of shale by ground oyster had limited effect.

It is well known that substratum orientation can alter the environmental conditions around the substrate such as temperature, light and disturbance (Davies et al. 2014; Firth et al. 2014a; Firth et al. 2016c; Irving and Connell 2002; Miller and Etter 2008) resulting in differences in community structure. In this experiment, downward-facing tiles were, in the first 4 months, characterised by different communities and more rapid 
colonisation and greater percentage of live cover than upward-facing tiles. Upward-facing surfaces, especially those without added heterogeneity, were colonised by red and green algae, which in shallow subtidal ecosystems is unsurprising as direct illumination favours photosynthesis and growth (Irving and Connell 2002; Miller and Etter 2008, but see Hansson 1995). In contrast, downward-facing shaded surfaces were dominated by a diverse range of sessile invertebrates; the early life-history stages of which are typically sciaphilic, and use a combination of synchronous spawning and negative phototaxis to facilitate recruitment into shaded habitat (Svane and Havenhand 1993).

Species prevalent on the downward-facing surfaces early on, such as the fast-growing ascidian Ciona intestinalis, are often considered opportunistic (i.e. r-strategists). They can rapidly form dense single-speciesdominated assemblages (Bracewell et al. 2013) that dominate competitive interactions (Jackson 1977) but also experience intense intraspecific competition that leads to rapid die-off (sensu "boom-bust" species; Price 1999). This "boom-bust" cycle was clearly evident in the change in number of OTUs and percentage live cover, where rapid increases in percentage live cover in Month 2 let to marked reduction in the number of OTUs in Month 3 and percentage live cover in Month 4. Following this "bust" phase, newly available space was gradually occupied by less opportunistic and long-lived species (k-strategists).

The addition of surface heterogeneity using relatively simple uniform channels led to a greater number of species overall, as well as increasing percentage cover by colonial organisms on upward-facing surfaces. Surface heterogeneity is well known to facilitate recruitment of species depending on its scale (Firth et al. 2014b; Moschella et al. 2005). At larger spatial scales ( $\mathrm{cm}$ to $\mathrm{m}$ ), the introduction of pits (Sella and Perkol-Finkel 2015), water retaining features (e.g. Chapman and Blockley 2009; Evans et al. 2016; Firth et al. 2016a) and grooves (Borsje et al. 2011; Coombes et al. 2015) can provide suitable habitat and refuge for larger species. At the sub-centimetre scale, species such as barnacles, rock borers and oysters, have been shown to utilise small imperfections such as the tiny air pockets created during concrete manufacture as habitat. This fine-scale rugosity, although not explored here, can facilitate recruitment of rugophilic species by providing an initial key for biological glues or providing increased protection (Coombes et al. 2015). (Nadine Hanlon, pers. obs.) indicating alteration of the boundary layer dynamics flowing over the surface of the concrete. Surface roughness has been shown to increase drag, reduce maximum water flow speed and create turbulent eddies over biogenic reefs (Loke et al. 2017; Whitman and Reidenbach 2012). These processes can facilitate the retention and aggregation of abiotic propagules (e.g. sediment) on upward-facing or sheltered substrates, effectively creating a layer of sedimentary habitat in an environment usually characterised by high shear (Airoldi and Cinelli 1997). This created a fundamentally different niche to that on low heterogeneity upward-facing surfaces that did not retain sediment. It is therefore unsurprising that the relative importance of heterogeneity in affecting community structure on upward and downward-facing surfaces was different. 
dominated upward-facing surfaces, and soft-bottom species were absent from downward-facing surfaces. Changes in boundary layer dynamics may also alter biotic interactions with the substrate. Reductions in flow velocity can increase contact or 'hitting' time (McNair et al. 1997) leading to a greater probability of successful attachment to the surface (Crimaldi et al. 2002), increase propagule abundance and retention (Abelson and Denny 1997; Knights et al. 2012; Knights and Walters 2010) and enhance preferential habitat selection (North et al. 2008), especially in bivalves and other encrusting species.

Chemical cues and biofilms are also considered important drivers of population and community dynamics, affecting conspecific and heterospecific settlement (Crisp 1967; Turner et al. 1994; Vasquez et al. 2013), or predator-prey interactions (Dixson et al. 2010; Weissburg et al. 2014). We expected the inclusion of ground oyster shell to enhance bivalve recruitment; the hypothesis being that the shell would introduce a chemical cue that increases recruitment (e.g. Browne and Zimmer 2001; Vasquez et al. 2013). The replacement of shale with ground oyster shell had only a marginal effect on the emergent communities as a whole although there was a significant increase in the abundance of molluscs recruited on tiles. Bivalves, in particular, have been shown to settle in response to heterospecific cues within the same family (Vasquez et al. 2013) suggesting that the replacement of shale for ground oyster shell may be a viable approach for enhancing oyster recruitment on CMI. For other taxa, the perception of, or response to, chemical cues may be in part overridden by the chemical properties of the concrete. Concrete is typically characterised by a high pH ( 13), which is toxic to some marine life (Lukens and Selberg 2004) and has been shown to inhibit settlement, growth and survival of benthic organisms (Connell and Glasby 1999; Lee et al. 2017). Perkol-Finkel and Sella (2014) demonstrated that reducing alkalinity by the use of different composites in the concrete could increase percentage live cover and enhance the recruitment of ecosystem engineers. Conversely, increasing acidity has also been shown to change 'perception' of chemical cues, significantly altering predator-prey dynamics in larval fish (Dixson et al. 2010) and bivalves (Sadler et al. 2018), and the recruitment of meiofauna (Lee et al. 2017). Oyster settlement can be induced by the glycyl-glycly-L-arginine (GGR) protein, produced within the shell (Crisp 1967), but it is only effective once larvae are within close proximity $(\mathrm{cm}-\mathrm{mm})$ of the surface bound cue (Browne and Zimmer 2001). In nature, detection and reaction to that cue is reliant on the concentration of waterborne cues from live conspecifics (Crisp 1967), conspecific noise (Lillis et al. 2013), and flow regimes (Knights and Walters 2010; Turner et al. 1994). As such, while these data suggest there may be some benefit of the use of cues for attracting some taxa, it remains unclear as to how extensive the effects might be for whole communities.

Our results show multiple recruitment drivers affect the emergent communities of artificial structures, and the effect of those drivers is time-dependent. Disentangling the effects of multiple recruitment drivers can be difficult, and mechanisms may not be clear-cut. Both sessile invertebrates and algae are known to respond (negatively or positively) to light and clear differences in the communities were apparent here; although other factors including disturbance, sedimentation (Irving and Connell 2002) or interspecific competition for space (Anderson and Underwood 1994; Miller and Etter 2008) are also likely to play important roles. In this study, we did not explicitly test for the effects of light, disturbance or boundary layer conditions on community dynamics, 
which we can only infer as possible contributing drivers of community patterns. Neither can we determine the relative weighting of these processes in the emergent community structure. Understanding the contribution of multiple drivers to community structure remains a challenge to ecology (Martorell and Freckleton 2014; Widder et al. 2016), affecting our ability to predict outcomes of interactions, such that the emergent outcomes are often context specific or time-sensitive.

It is often reported that artificial structures are typically depauperate of species, yet we found a diverse range of species on the artificial structures. Many of the species that recruited during this experiment were ecosystem engineers, adding three-dimensional space to the existing surface and facilitating the recruitment of later arriving invertebrates through the provision of biogenic habitat structure (Thompson et al. 1996). Biogenic build-up can protect artificial structures from weathering and erosion and enhance their longevity (Coombes et al. 2013) providing an important regulating ecosystem service. These species tended to be more strongly associated with downward-facing (shaded) surfaces, although the dissimilarity between downward and upward-facing communities could be partly mitigated by the addition of heterogeneity to upward-facing surfaces. Given the increasing prevalence of artificial structures in the marine environment (Firth et al. 2016), our results show how a simple, cheap and easy to implement modification of the artificial surface, especially on illuminated (upward-facing) surfaces, can act as important mechanism for promoting recruitment and colonisation of surfaces by plants and animals that enhances biodiversity and improves the resilience of artificial structures to weathering without compromising structural integrity. It is suggested that this modification could be applied to all new structures.

The replacement of shale for ground oyster yielded only marginal increases in the abundance of ecosystem engineers despite previous studies arguing for the importance of olfactory cues during the recruitment process (e.g. O'Connor et al. 2008). Our findings therefore suggest a number of logical next steps for research. One is to explore whether the chemical signature of concrete (e.g. its alkalinity; Sella \& Perkol-Finkel, 2015) alters the magnitude of a biological settlement response to a cue i.e. does the alkalinity of the surface alter the perception of biological cues by potential recruits and thus modify the efficacy of shale replacement in promoting settlement? Another is to consider the choice of biological material used to replace the shale component in the concrete. It may be that $M$. gigas is not a particularly important settlement cue. Future trials should therefore consider the replacement of shale with other biogenic materials (e.g. mussel shell) or combinations of biogenic materials, which will shed further light on the extent to which the choice of biogenic material can act as a selection mechanism for certain (targeted) species or biodiversity in general.

Overall, it is apparent that innovative engineering design that uses a combination of shade and addition of heterogeneity can provide a mechanism, not just to provide space for nature on CMI but to faciliate selected recruitment of certain ecologically-important phyla. Understanding how to design and build CMI that attracts recruitment by target species is the next step in designing functional artificial structures that also compensate for the loss of natural habitat as a result of ocean sprawl. 


\section{ACKNOWLEDGEMENTS}

443 The authors wish to thank the Oyster Shack, Bigbury for supplying oyster shells, and Michael Hanlon for

444 constructing the moulds, and for providing guidance and facilities to make the tiles. We would also like to thank

445 Richard Ticehurst, Roger Hallam, Sarah Curtin and Sophie Donaldson for their help with fieldwork and species

446 identification. Funding support was provided by the University of Plymouth.

447

448 


\section{References}

Abelson, A., Denny, M., 1997. Settlement of marine organisms in flow. Annual Review of Ecology and Systematics. 28:317-339

Abramoff, M.D., Magalhaes, P.J., Ram, S.J., 2004. Image processing with ImageJ. Biophotonics International. 11:36-42

Airoldi, L., 2003. The effects of sedimentation on rocky coast assemblages. Oceanography and Marine Biology, Vol 41. 41:161-236

Airoldi, L., Beck, M.W., 2007. Loss, status and trends for coastal marine habitats of Europe. Oceanography and Marine Biology, Vol 45. 45:345-405

Airoldi, L., Bulleri, F., 2011. Anthropogenic disturbance can determine the magnitude of opportunistic species responses on marine urban infrastructures. Plos One. 6

Airoldi, L., Cinelli, F., 1997. Effects of sedimentation on subtidal macroalgal assemblages: An experimental study from a Mediterranean rocky shore. J Exp Mar Biol Ecol. 215:269-288

Airoldi, L., Turon, X., Perkol-Finkel, S., Ruis, M., 2015. Corridors for aliens but not for natives: effects on marine urban sprawl at a regional scale. Diversity and Distributions. 21:755-768

Anderson, M.J. 2003 NPMANOVA. Auckland, New Zealand: Department of Statistics, University of Auckland

Anderson, M.J., Underwood, A.J., 1994. Effects of substratum on the recruitment and development of an intertidal estuarine fouling assemblage. J Exp Mar Biol Ecol. 184:217-236

Barnes, B.B., Luckenbach, M.W., Kingsley-Smith, P.R., 2010. Oyster reef community interactions: The effect of resident fauna on oyster (Crassostrea spp.) larval recruitment. J Exp Mar Biol Ecol. 391:169-177

Bishop, M.J., Mayer-Pinto, M., Airoldi, L., Firth, L.B., Morris, R.L., Loke, L.H.L., Hawkins, S.J., Naylor, L.A., Coleman, R.A., Chee, S.Y., Dafforn, K.A., 2017. Effects of ocean sprawl on ecological connectivity: impacts and solutions. J Exp Mar Biol Ecol. 492:7-30

Borsje, B.W., van Wesenbeeck, B.K., Dekker, F., Paalvast, P., Bouma, T.J., van Katwijk, M.M., de Vries, M.B., 2011. How ecological engineering can serve in coastal protection. Ecological Engineering. 37:113-122

Bracewell, S.A., Robinson, L.A., Firth, L.B., Knights, A.M., 2013. Predicting free-space occupancy on novel artificial structures by an invasive intertidal barnacle using a removal experiment. Plos One. 8:1-7

Bracewell, S.A., Spencer, M., Marrs, R.H., Iles, M., Robinson, L.A., 2012. Cleft, crevice, or the inner thigh: 'Another Place' for the establishment of the invasive barnacle Austrominius modestus (Darwin, 1854). Plos One. 7:e48863

Browne, K.A., Zimmer, R.K., 2001. Controlled field release of a waterborne chemical signal stimulates planktonic larvae to settle. Biological Bulletin. 200:87-91

Chapman, M.G., 2003. Paucity of mobile species on constructed seawalls: effects of urbanization on biodiversity. Mar Ecol Prog Ser. 264:21-29

Chapman, M.G., Blockley, D.J., 2009. Engineering novel habitats on urban infrastructure to increase intertidal biodiversity. Oecologia. 161:625-635

Chee, S.Y., Othman, A.G., Sim, Y.K., Adam, A.N.M., Firth, L.B., 2017. Land reclamation and artificial islands: Walking the tightrope between development and conservation. Glob Ecol Conserv. 12:80-95

Clarke, K.R., Warwick, R.M., 1998. Quantifying structural redundancy in ecological communities. Oecologia. 113:278-289

Cole, H., Knight Jones, E., 1939. Some observations and experiments on the settling behaviour of larvae of Ostrea edulis. ICES Journal of Marine Science. 14:86-105

Collins, K.J., Jensen, A.C., Mallinson, J.J., Roenelle, V., Smith, I.P., 2002. Environmental impact assessment of a scrap tyre artificial reef. Ices Journal of Marine Science. 59:S243-S249

Connell, S.D., Glasby, T.M., 1999. Do urban structures influence local abundance and diversity of subtidal epibiota? A case study from Sydney Harbour, Australia. Marine Environmental Research. 47:373-387

Coombes, M.A., La Marca, E.C., Naylor, L.A., Thompson, R.C., 2015. Getting into the groove: Opportunities to enhance the ecological value of hard coastal infrastructure using fine-scale surface textures. Ecological Engineering. 77:314-323

Coombes, M.A., Naylor, L.A., Viles, H.A., Thompson, R.C., 2013. Bioprotection and disturbance: Seaweed, microclimatic stability and conditions for mechanical weathering in the intertidal zone. Geomorphology. 202:4-14

Coombes, M.A., Viles, H.A., Naylor, L.A., La Marca, E.C., 2017. Cool barnacles: Do common biogenic structures enhance or retard rates of deterioration of intertidal rocks and concrete? Sci Total Environ. 580:10341045 
Crimaldi, J., Thompson, J., Rosman, J., Lowe, R., Koseff, J., 2002. Hydrodynamics of larval settlement: the influence of turbulent stress events at potential recruitment sites. Limnol Oceanogr. 47:1137-1151

Crisp, D., Ryland, J., 1960. Influence of filming and of surface texture on the settlement of marine organisms. Nature. 185:119

Crisp, D.J., 1967. Chemical factors inducing settlement in Crassostrea virginica (Gmelin). J Anim Ecol. 36:329335

Crossland, C.J., Baird, D., Ducrotoy, J.P., Lindeboom, H., Buddemeier, R.W., Dennison, W.C., Maxwell, B.A., Smith, S.V., Swaney, D.P., 2005. The coastal zone-a domain of global interactions. Berlin: Springer

Davies, T.W., Duffy, J.P., Bennie, J., Gaston, K.J., 2014. The nature, extent, and ecological implications of marine light pollution. Front Ecol Environ. 12:347-355

Diederich, S., 2005. Differential recruitment of introduced Pacific oysters and native mussels at the North Sea coast: coexistence possible? J Sea Res. 53:269-281

Dixson, D.L., Munday, P.L., Jones, G.P., 2010. Ocean acidification disrupts the innate ability of fish to detect predator olfactory cues. Ecol Lett. 13:68-75

Dubois, S., Retiere, C., Olivier, F., 2002. Biodiversity associated with Sabellaria alveolata (Polychaeta : Sabellariidae) reefs: effects of human disturbances. J Mar Biol Assoc UK. 82:817-826

Evans, A.J., Firth, L.B., Hawkins, S.J., Morris, E.S., Goudge, H., Moore, P.J., 2016. Drill-cored rock pools: an effective method of ecological enhancement on artificial structures. Marine and Freshwater Research. 67:123-130

Firth, L.B., Browne, K.A., Knights, A.M., Hawkins, S.J., Nash, R., 2016a. Eco-engineered rock pools: a concrete solution to biodiversity loss and urban sprawl in the marine environment. Environ Res Lett. 11

Firth, L.B., Knights, A.M., Bridger, D., Evans, A., Mieskowska, N., Moore, P.J., O'Connor, N.E., Sheehan, E.V., Thompson, R.J., Hawkins, S.J., 2016b. "Ocean sprawl" in a changing world: Challenges and opportunities for managing biodiversity. Oceanography and Marine Biology - An Annual Review. 54

Firth, L.B., Schofield, M., White, F.J., Skov, M.W., Hawkins, S.J., 2014a. Biodiversity in intertidal rock pools: Informing engineering criteria for artificial habitat enhancement in the built environment. Marine Environmental Research. 102:122-130

Firth, L.B., Thompson, R.C., Bohn, K., Abbiati, M., Airoldi, L., Bouma, T.J., Bozzeda, F., Ceccherelli, V.U., Colangelo, M.A., Evans, A., Ferrario, F., Hanley, M.E., Hinz, H., Hoggart, S.P.G., Jackson, J.E., Moore, P., Morgan, E.H., Perkol-Finkel, S., Skov, M.W., Strain, E.M., van Belzen, J., Hawkins, S.J., 2014b. Between a rock and a hard place: Environmental and engineering considerations when designing coastal defence structures. Coastal Engineering. 87:122-135

Firth, L.B., Thompson, R.C., White, R.F., Schofield, M., Skov, M.W., Hoggart, S.P.G., Jackson, J., Knights, A.M., Hawkins, S.J., 2013. The importance of water retaining features for biodiversity on artificial intertidal coastal defence structures. Diversity and Distributions. 19:1275-1283

Firth, L.B., White, F.J., Schofield, M., Hanley, M.E., Burrows, M.T., Thompson, R.C., Skov, M.W., Evans, A.J., Moore, P.J., Hawkins, S.J., 2016c. Facing the future: the importance of substratum features for ecological engineering of artificial habitats in the rocky intertidal. Marine and Freshwater Research. 67:131-143

Gerland, P., Raftery, A.E., Sevcikova, H., Li, N., Gu, D.A., Spoorenberg, T., Alkema, L., Fosdick, B.K., Chunn, J., Lalic, N., Bay, G., Buettner, T., Heilig, G.K., Wilmoth, J., 2014. World population stabilization unlikely this century. Science. 346:234-237

Glasby, T.M., Connell, S.D., Holloway, M.G., Hewitt, C.L., 2007. Nonindigenous biota on artificial structures: could habitat creation facilitate biological invasions? Mar Biol. 151:887-895

Hadfield, M.G., Koehl, M.A.R., 2001. Dissolved cues to invertebrate larval settlement: do they work in moving water? American Zoologist. 41:1462-1462

Hansson, L.A., 1995. Diurnal recruitment patterns in algae - effects of light cycles and stratified conditions. J Phycol. 31:540-546

Hauser, A., Attrill, M.J., Cotton, P.A., 2006. Effects of habitat complexity on the diversity and abundance of macrofauna colonising artificial kelp holdfasts. Mar Ecol Prog Ser. 325:93-100

Hay, M.E., 2009. Marine chemical ecology: Chemical signals and cues structure marine populations, communities, and ecosystems. Annu Rev Mar Sci. 1:193-212

Huston, M.A., 1979. General hypothesis of species diversity. American Naturalist. 113:81-101

Irving, A.D., Connell, S.D., 2002. Sedimentation and light penetration interact to maintain heterogeneity of subtidal habitats: algal versus invertebrate dominated assemblages. Mar Ecol Prog Ser. 245:83-91

Kawabata, Y., Kato, E., Iwanami, M., 2012. Enhanced long-term resistance of concrete with marine sessile organisms to Chloride ion penetration. J Adv Concr Technol. 10:151-159 
Knights, A.M., Firth, L.B., Thompson, R.C., Yunnie, A.L.E., Hiscock, K., Hawkins, S.J., 2016. Plymouth - A World Harbour through the ages. Regional Studies in Marine Science

Knights, A.M., Firth, L.B., Walters, K., 2012. Interactions between multiple recruitment drivers: post-settlement predation mortality overrides flow-mediated recruitment. Plos One. 7:e35096

Knights, A.M., Piet, G.J., Jongbloed, R., Tamis, J.E., Churilova, T., Fleming-Lehtinen, V., Galil, B.S., Goodsir, F., Goren, M., Margonski, P., Moncheva, S., Papadopoulou, K.N., Setälä, O., Smith, C., Stefanova, K., Timofte, F., White, L.J., Robinson, L.A., 2015. An exposure-effect approach for evaluating ecosystemwide risks from human activities. ICES Journal of Marine Science. 72:1105-1115

Knights, A.M., Walters, K., 2010. Recruit-recruit interactions, density-dependent processes and population persistence in the eastern oyster Crassostrea virginica. Mar Ecol Prog Ser. 404:79-90

Knott, N.A., Underwood, A.J., Chapman, M.G., Glasby, T.M., 2004. Epibiota on vertical and on horizontal surfaces on natural reefs and on artificial structures. J Mar Biol Assoc UK. 84:1117-1130

Lee, M.R., Torres, R., Manriquez, P.H., 2017. The combined effects of ocean warming and acidification on shallow-water meiofaunal assemblages. Marine Environmental Research. 131:1-9

Lillis, A., Eggleston, D.B., Bohnenstiehl, D.R., 2013. Oyster larvae settle in response to habitat-associated underwater sounds. Plos One. 8

Loke, L.H.L., Bouma, T.J., Todd, P.A., 2017. The effects of manipulating microhabitat size and variability on tropical seawall biodiversity: field and flume experiments. J Exp Mar Biol Ecol. 492:113-120

Loke, L.H.L., Ladle, R.J., Bouma, T.J., Todd, P.A., 2015. Creating complex habitats for restoration and reconciliation. Ecological Engineering. 77:307-313

Loke, L.H.L., Todd, P.A., 2016. Structural complexity and component type increase intertidal biodiversity independently of area. Ecology. 97:383-393

Lukens, R.R., Selberg, C. 2004 Guidelines for Marine Artificial Reef Materials. A Joint Publication of the Gulf and Atlantic States Marine Fisheries Commission

Martorell, C., Freckleton, R.P., 2014. Testing the roles of competition, facilitation and stochasticity on community structure in a species-rich assemblage. Journal of Ecology. 102:74-85

McManus, R.S., Archibald, N., Comber, S., Knights, A.M., Thompson, R.C., Firth, L.B., 2017. Partial replacement of cement for waste aggregates in concrete coastal and marine infrastructure: A foundation for ecological enhancement? Ecological Engineering

McNair, J.N., Newbold, J.D., Hart, D.D., 1997. Turbulent transport of suspended particles and dispersing benthic organisms: how long to hit bottom? Journal of Theoretical Biology. 188:29-52

Miller, R.J., Etter, R.J., 2008. Shading facilitates sessile invertebrate dominance in the rocky subtidal Gulf of Maine. Ecology. 89:452-462

Mitsch, W.J., 2012. What is ecological engineering? Ecological Engineering. 45:5-12

Moschella, P.S., Abbiati, M., Åberg, P., Airoldi, L., Anderson, J.M., Bacchiocchi, F., Bulleri, F., Dinesen, G.E., Frost, M., Gacia, E., Granhag, L., Jonsson, P.R., Satta, M.P., Sundelöf, A., Thompson, R.C., Hawkins, S.J., 2005. Low-crested coastal defence structures as artificial habitats for marine life: Using ecological criteria in design. Coastal Engineering. 52:1053-1071

Nandakumar, K., 1996. Importance of timing of panel exposure on the competitive outcome and succession of sessile organisms. Mar Ecol Prog Ser. 131:191-203

Nandakumar, K., Matsunaga, H., Takagi, M., 2003. Microfouling studies on experimental test blocks of steelmaking slag and concrete exposed to seawater off Chiba, Japan. Biofouling. 19:257-267

Neo, M.L., Todd, P.A., Teo, S.L.M., Chou, L.M., 2009. Can artificial substrates enriched with crustose coralline algae enhance larval settlement and recruitment in the fluted giant clam (Tridacna squamosa)? Hydrobiologia. 625:83-90

Neumann, B., Vafeidis, A.T., Zimmermann, J., Nicholls, R.J., 2015. Future coastal population growth and exposure to sea-level rise and coastal flooding - A global assessment Plos One. 10

North, E.W., Schlag, Z., Hood, R.R., Li, M., Zhong, L., Gross, T., Kennedy, V.S., 2008. Vertical swimming behavior influences the dispersal of simulated oyster larvae in a coupled particle-tracking and hydrodynamic model of Chesapeake Bay. Mar Ecol Prog Ser. 359:99-115

O'Connor, N.E., Grabowski, J.H., Ladwig, L.M., Bruno, J.F., 2008. Simulated predator extinctions: predator identity affects survival and recruitment of oysters. Ecology. 89:428-438

Oksanen, J., Blanchet, F.G., Kindt, R., Legendre, P., Minchin, P.R., O'Hara, R.B., Simpson, G.L., Solymos, P., Stevens, M.H.H., Wagner, H. 2016 vegan: Community Ecology Package.

Paul, V.J., Ritson-Williams, R., Sharp, K., 2011. Marine chemical ecology in benthic environments. Natural Product Reports. 28:345-387 
Pawlik, J.R., 1992. Chemical ecology of the settlement of benthic marine invertebrates. Oceanography and Marine Biology Annual Review. 30:273-335

Pomerat, C., Weiss, C., 1946. The influence of texture and composition of surface on the attachment of sedentary marine organisms. Biological Bulletin. 91:57-65

Price, D., 1999. Carrying capacity reconsidered. Popul Environ. 21:5-26

R Development Core Team, 2017. R: A language and environment for statistical computing. Vienna, Austria: R Foundation for Statistical Computing

Roberts, D., Rittschof, D., Holm, E., Schmidt, A.R., 1991. Factors influencing initial larval settlement - temporal, spatial and surface molecular components. J Exp Mar Biol Ecol. 150:203-221

Sadler, D.E., Lemasson, A.J., Knights, A.M., 2018. The effects of elevated $\mathrm{CO}_{2}$ on shell properties and susceptibility to predation in mussels Mytilus edulis. Marine Environmental Research:1-7

Sawall, Y., Richter, C., Ramette, A., 2012. Effects of eutrophication, seasonality and macrofouling on the diversity of bacterial biofilms in equatorial coral reefs. Plos One. 7

Sella, I., Perkol-Finkel, S., 2015. Blue is the new green - Ecological enhancement of concrete-based coastal and marine infrastructure. Ecological Engineering. 84:260-272

Strain, E.M.A., Olabarria, C., Mayer-Pinto, M., Cumbo, V., Morris, R.L., Bugnot, A.B., Dafforn, K.A., Heery, E., Firth, L.B., Brooks, P.R., Bishop, M.J., 2018. Eco-engineering urban infrastructure for marine and coastal biodiversity: Which interventions have the greatest ecological benefit? J Appl Ecol. 55:426-441

Svane, I., Havenhand, J.N., 1993. Spawning and dispersal in Ciona intestinalis (L). Marine Ecology-Pubblicazioni Della Stazione Zoologica Di Napoli I. 14:53-66

Tamburri, M.N., Zimmerfaust, R.K., Tamplin, M.L., 1992. Natural sources and properties of chemical inducers mediating settlement of oyster larvae - a reexamination. Biological Bulletin. 183:327-338

Thompson, R.C., Wilson, B.J., Tobin, M.L., Hill, A.S., Hawkins, S.J., 1996. Biologically generated habitat provision and diversity of rocky shore organisms at a hierarchy of spatial scales. J Exp Mar Biol Ecol. 202:73-84

Thorson, G., 1964. Light as an ecological factor in the dispersal and settlement of larvae of marine bottom invertebrates. Ophelia. 1:167-208

Turner, E.J., Zimmer-Faust, R.K., Palmer, M.A., Luckenback, M., 1994. Settlement of oyster (Crassostrea virginica) larvae: effects of water flow and a water-soluble chemical cue. Limnol Oceanogr. 39:15791593

Underwood, A.J., Anderson, M.J., 1994. Seasonal and temporal aspects of recruitment and succession in an intertidal estuarine fouling assemblage. J Mar Biol Assoc UK. 74:563-584

Vasquez, H.E., Hashimoto, K., Yoshida, A., Hara, K., Imai, C.C., Kitamura, H., Satuito, C.G., 2013. A glycoprotein in shells of conspecifics induces larval settlement of the Pacific oyster Crassostrea gigas. Plos One. 8

Vermeij, M.J.A., Bak, R.P.M., 2002. How are coral populations structured by light? Marine light regimes and the distribution of Madracis. Mar Ecol Prog Ser. 233:105-116

Weissburg, M., Smee, D.L., Ferner, M.C., 2014. The sensory ecology of non-consumptive predator effects. American Naturalist. 184:141-157

Whitman, E.R., Reidenbach, M.A., 2012. Benthic flow environments affect recruitment of Crassostrea virginica larvae to an intertidal oyster reef. Mar Ecol Prog Ser. 463:177-191

Widder, S., Allen, R.J., Pfeiffer, T., Curtis, T.P., Wiuf, C., Sloan, W.T., Cordero, O.X., Brown, S.P., Momeni, B., Shou, W., Kettle, H., 2016. Challenges in microbial ecology: building predictive understanding of community function and dynamics. The ISME Journal. 10:2557 
662 Appendix 1: Species identified during destructive sampling after six months

\begin{tabular}{|c|c|}
\hline Phyla & Species \\
\hline \multirow[t]{3}{*}{ Porifera } & 1 Sycon ciliatum \\
\hline & 2 Halichondria panicea \\
\hline & 3 Leucosolenia botryoides \\
\hline Cnidaria & $4 \quad$ Actinia equina \\
\hline \multirow[t]{5}{*}{ Platyhelminthes } & $5 \quad$ Leptoplana tremallaris \\
\hline & $6 \quad$ Eurynepta cornuta \\
\hline & $7 \quad$ Stylostomum ellipse \\
\hline & $8 \quad$ Plagiostomum sulphueum \\
\hline & $9 \quad$ Flat worm1 sp. \\
\hline \multirow[t]{4}{*}{ Nemertea } & 10 Emplectonema gracile \\
\hline & 11 Nemertea flavida \\
\hline & 12 Lineus albocinctus \\
\hline & 13 Vieitezia luzmurubeae \\
\hline \multirow[t]{20}{*}{ Annelida } & 14 Tetrastemma flavidum \\
\hline & 15 Tetrastemma herouardi \\
\hline & 16 Alentia gelatinosa \\
\hline & 17 Lepidonotus clava \\
\hline & 18 Cirratulus cirratus \\
\hline & 19 Ophryotrocha puerilis \\
\hline & 20 Psamathe fusca \\
\hline & 21 Micronereis variegata \\
\hline & 22 Platynereis species \\
\hline & 23 Phyllodoce mucosa \\
\hline & 24 Nereiphylla rubiginosa \\
\hline & 25 Amblyosyllis formosa \\
\hline & 26 Eupolymnia nebulosa \\
\hline & 27 Lanice conchilega \\
\hline & 28 Polycirrus caliendrum \\
\hline & 29 Branchiomma bombyx \\
\hline & 30 Pseudopotamilla reniformis \\
\hline & 31 Sabella pavonina \\
\hline & 32 Pomatoceros lamarcki \\
\hline & 33 Pomatoceros triquiter \\
\hline
\end{tabular}




\begin{tabular}{|c|c|c|}
\hline & 34 & Spirobis sp. \\
\hline \multirow[t]{6}{*}{ Crustacea } & 35 & Austrominius modestus \\
\hline & 36 & Eurydice affinis \\
\hline & 37 & Gammarus sp. \\
\hline & 38 & Caprella sp. \\
\hline & 39 & Cancer pagurus \\
\hline & & Rhithropanopeus harrisii \\
\hline \multirow[t]{2}{*}{ Arthropoda } & 41 & Endeis spinosa \\
\hline & & Pycnogonida sp \\
\hline \multirow[t]{16}{*}{ Mollusca } & 43 & Acanthochitona crinitus \\
\hline & & Rissoa parva \\
\hline & 45 & Crepidula fornicata \\
\hline & & Runcina coronata \\
\hline & 47 & Goniodoris castanea \\
\hline & 48 & Goniodoris nodosa \\
\hline & 49 & Philine aperta \\
\hline & 50 & Polycera quadrilineata \\
\hline & 51 & Janolus hyalinus \\
\hline & 52 & Anomia ephippium \\
\hline & 53 & Mytillidae sp. \\
\hline & 54 & Mytilus edulis \\
\hline & & Musculas costulatas \\
\hline & 56 & Pectinidae sp. \\
\hline & & Hiatella arctica \\
\hline & 58 & Nudibranch sp. egg mass \\
\hline \multirow[t]{6}{*}{ Bryozoa } & 59 & Crisularia plumosa \\
\hline & 60 & Watersipora subtorquata \\
\hline & 61 & Membranipora membranacea \\
\hline & 62 & Bugula neritina \\
\hline & 63 & Bugulina stolonifera \\
\hline & 64 & Schizomavella linearis \\
\hline \multirow[t]{2}{*}{ Echinodermata } & 65 & Asterina gibbosa \\
\hline & 66 & Starfish sp. larvae \\
\hline \multirow[t]{4}{*}{ Chordata } & 67 & Ciona intestinalis \\
\hline & 68 & Clavelina lepadiformis \\
\hline & 69 & Didemnum maculosum \\
\hline & 70 & Diplosoma spongiforme \\
\hline
\end{tabular}




\begin{tabular}{|l|ll|} 
& 71 & Ascidiella aspersa \\
\hline & 72 & Ascidiella scabra \\
\hline & 73 & Asterocarpa humilis \\
\hline & 74 & Phallusia mammillata \\
\hline & 75 & Dendrodoa grossularia \\
\hline & 76 & Stolonica socialis \\
\hline & 77 & Botrylloides violaceus \\
\hline Protozoa & 78 & Ascidia sp. egg mass \\
\hline Chlorophyta & 80 & Folliculina sp. \\
\hline Rhodophyta & 81 & Pterothamnion plumula \\
\hline
\end{tabular}

663

664 